\title{
NRP2 wt Allele
}

National Cancer Institute

\section{Source}

National Cancer Institute. NRP2 wt Allele. NCI Thesaurus. Code C74469.

Human NRP2 wild-type allele is located in the vicinity of 2 q33.3 and is approximately 116 $\mathrm{kb}$ in length. This allele, which encodes neuropilin-2 protein, is involved in the mediation of signal transduction associated with cardiovascular development, axon guidance, and tumorigenesis. Aberrant expression of the gene may contribute to colon cancer and autism. 